\title{
A Needs Analysis of Historical Learning Model to Reinforce Student's Local Character Using Local Wisdom Values of Turonggo Yakso Art
}

\author{
Nenin Al Alaz*, Nunuk Suryani, Djono \\ Faculty of Teacher Training and Education, UNS, Sebelas Maret University, Surakarta, Indonesia \\ Received 02 August 2018 \\ Revised 04 November 2018; Accepted 27 November 2018
}

\begin{abstract}
This research is part of the initial development activities to find out the problems that occur in schools so that model development needs to be done. The problem that happened in SMA Negeri 1 Panggul, Trenggalek, East Java is the lack of ecological intelligence of students this is evidenced by the school yard still scattered with garbage, students still use non-biodegradable waste and concern for the impact of goods consumed is still low. Student environment as part of student life is an important point to be developed as an effort to fix the problem. One effort that can be done as a school channel of education distributors is to integrate the local values in the community into the curriculum and learning unit. One of the local values that have the meaning of ecological wisdom is the values of the local wisdom of Turonggo Yakso art that is still thick with Javanese culture. The values of the local wisdom of Turonggo Yakso art have the highest values that can be a reference for someone to act and have been known by most people of Trenggalek district. The values contained in the art of Turonggo Yakso are not widely known and applied by the students, therefore they need to be revitalized through the education system. This study used a descriptive qualitative method with interviews of teachers and students and lesson plan document analysis (RPP), curriculum and syllabus used in learning. The results of the interview and questionnaires analysis suggest that teachers need to develop a learning model based on local wisdom values of Turonggo Yakso art as an effort to improve the learning problems at school. Ecological intelligence needs to be owned by students as the agent of change to be able to participate in doing sustainable development in facing the challenge of globalization and have good character to the natural environment.
\end{abstract}

Keywords: Need analysis, historical learning, model, reinforce, student, local character, local wisdom, values, Turonggo Yakso Art.

\section{Introduction}

A needs analysis in the study was conducted to determine the needs of students in

\footnotetext{
* Corresponding author. Tel.: 082336191858.

Email: neninalz27@gmail.com
}

https://doi.org/10.25073/2588-1159/vnuer.4163 the learning process in order to find an alternative problem solving. Needs analysis is an initial process of research that guides researchers to be able to develop a product that suits the needs in the field. Learning problems can be solved through instructional innovations tailored to the characteristics of students so that 
the usefulness of learning product development can be accepted and can solve problems facing teachers. Needs analysis on students conducted in SMA Negeri 1 Panggul done through an observation, interview and questionnaire. Local wisdom is the main cultural item developed in the education system of the Indonesian school curriculum. The curriculum is determined by the government,

Urgency of the development of the model of learning in the millenial era is more inclined to integrate the values of local wisdom applicable in the community. Local wisdom has a great influence on the formation of one's character. The values of local wisdom are the result of the highest culture inherited by the ancestors to the next generation. Education becomes a place that plays a role in conveying the values of local wisdom because oral culture is rarely done in the current era of globalization. The development and advancement of technology has affected the younger generation and not all that delivered through spoken can be easily accepted. The logic of students' thinking is more inclined to a logical question acceptable to human reason. These reasons affect the decline of the culture that has been formed. The existence of local cultural wisdom owned by the Indonesian nation is the wealth of the Indonesian nation that forms the character of its citizens. Culture of the nation can not be separated from the habits of the local community. Culture is formed through a unity of thought that is considered in accordance with the attitude that most of the community groups.

Culture is not power, something to which social events, behaviors, institutions, or processes can be casually attributed; it is a context, something within which they can be intelligibly that is thickly described (Geertz, 1973, p 14) [1]. Culture as a characteristic that influenced the dynamics of community life that can shift along with the dominance of other cultural power. The mentality of society determines the culture created as a result of the socialization process of a community group that produces values, norms, conceptions and the meaning of togetherness. The dynamics of people's lives can influence the development and/or cultural decline. This factor is adapted to the extent to which existing cultures are able to adapt to the new culture but still do not deprive the original cultural character. Infiltration outside culture through a technology, information and social media needs to be considered so that the culture that has formed remains firm.

Much moral decadence occurs in various regions of Indonesia such as drug use and criminality (theft, fraud). Local wisdom contains values that form a characteristic civilization of a human life. Patterns of behavior and attitudes are influenced by the personality of the individual which is the result of his interaction with the culture and society of the surrounding environment. The wave of modernization has been a whip for understanding and preserving local cultures so that people within them will not lose their identity. Coherence between the values of local wisdom and education is to build human beings of noble character and live their lives according to the rules and norms that apply.Education becomes a forum that channel knowledge both in local and global scope.

Education in schools is more normative, can be integrated with the values prevailing in the community in accordance with the curriculum. The acceleration of technology and information is not entirely positive, because the rapid development of technology causes dependence and the emergence of individualism. Globalization involves causing a person to adopt outside cultures and knowledge so that the habits performed in their local environment are incompatible with local values. The intensity of the growing cultural struggle becomes an influence for the mentality of distant society with the values of a locality. Aspects of government policy are prepared to accommodate cultural richness in various regions. 
The development of technology is a development in science and bring progress to the civilization of the nation. The worldview of the modern world gives birth to a paradigm of egocentrism. Nature is exploited on a large scale regardless of the need for more and more natural resources. Living beings are considered parallel to nature while nature is used as a place to meet human. Nature is part of a unity of life that must be preserved. The interests of consumerism make people exploit all the natural wealth to cause the effects of damage and natural becana. The lack of information and extension resources on the sustainability of natural resource development is increasingly eroding the natural resources. The ecological crisis and its complexity affect the pollution of the natural environment.

The use of technology, the exploitation of natural resources and various nonenvironmentally friendly goods result in ozone layer depletion, environmental pollution, drought, flooding and air pollution. All natural problems are common problems that must be solved by mutual cooperation. Therefore, to maintain the environment can be done by developing the potential of nature through the establishment of knowledge and use technology wisely. Environmental conditions are very considerate seen from lifestyle and human treatment of the natural environment. Education and learning is an effective means and vehicle to provide knowledge, awareness, and ability as well as to improve student behavior towards sustainability (Muhaimin, 2015, p.35) [2]. Behavior is based on the acquisition of sustainable knowledge through a steady learning process. Through learning, a person will have an understanding in acting and know the impact of his behavior.

Educational agents can use learning by integrating local wisdom values close to the student's environment. local wisdom is a local knowledge derived from the experience of community communities is used as a reference behavior and actions carried out by generations by the community (Kongprasertamorn, 2007, p 2) [3]. Local wisdom provides a basis for understanding traditional knowledge in order to meet the needs of external challenges. Local wisdom is meaningful for the life of the community as an effort to conserve people, culture, customs, natural resources, and human resources. The values of local wisdom of Turonggo Yakso art are the values depicted in the dance art of Turonggo Yakso originating from the Dongko region of Trenggalek. Ecological wisdom done by the local community is depicted through dance movements in art. The values contained in the local wisdom of the Turonggo Yakso arts include the value of environmental care, cultural values, and the value of mutual assistance which is the culture of the local community in interacting with nature and fellow beings.

Local wisdom values of Turonggo Yakso art can be integrated into historical learning. History has material that is based on the events of the age of light that can teach a person to the values of life made by human beings before. History is the construction and deconstruction of explanatory narratives about the past, derived from evidence and in the minds of the buildings (Bage, 2002, p.33) [4]. History serves to dismantle the values contained in the local wisdom of the art Turonggo Yakso, so the messages to be conveyed by the ancestors based on the current development of historical narratives built by the community. The ultimate goal of creating the Turonggo Yakso art values is a local genius to preserve the environment in order to communicate. Submission of these values is done through the integration of historical material relating to the topic of the material discussed. The values must also be adjusted to the values that have been formulated by the government through national education.

The results of human experience that is empirical obtained through interacting with the environment raises a wise attitude in the face of 
life's challenges. Local wisdom that has a rational meaning can be applied as an effort to protect the natural environment from natural disasters and destruction. The position of local wisdom is currently declining so it must be revitalized so that the values of local wisdom remains a reference for society to behave. The anthropocentric paradigm must be changed based on the awareness that the natural environment must be well cared for, thus providing benefits to human life.

\section{Methodology}

This study aims to determine the problems that occur in schools and provide an alternative problem solving through the subjects of history. In the first stage it is done through the examination of various literature, documents, research results, observation and interviews of teachers and students. (Strauss, 1997, p.11) [5], states that with qualitative research can be shown about community life, history, behavior, also about functionalization, organization, social movements or kinship. Needs analysis is done through interviews, distributing questionnaires and analysis of student documents in the form of transcripts of value, analysis of learning tools and materials taught. Needs analysis conducted in SMA Negeri 1 Panggul shows the problem that most students still have low level of ecological intelligence both seen from lifestyle, habits and what is consumed by students. Based on the results of an ecological intelligence questionnaire shows that there are still many students who use plastics, students whose homes nearby use motorcycles to school, causing pollution, littering, and not understanding the impact of food consumed. Data analysis using Miles and Huberman in (Sugiyono, 2012, p.337) [6] which is divided into three stages namely, data reduction, data preparation and conclusion/verification.

\subsection{Result need analysis values of local wisdom of art Turonggo Yakso}

The values of local wisdom of Turonggo Yakso art have the highest values in culture in Trenggalek area. The art of its dance favored many people have a mix of movements that tell the stage of agriculture and show ecological wisdom owned by the community. The values of local wisdom have not been widely known by most students at various levels of education because each dance performances only show the harmony of movement. Art Turonggo Yakso known as jaranan dance art that exist in the region of Central Java in general, while the art of dance Turonggo Yakso has quite striking difference. Students in Trenggalek schools teach Turonggo Yakso dance but do not explore the values that are in it.

Exploitation of local wisdom values Turonggo Yakso art has not been done by educational agencies in schools in Trenggalek area. Cultural wealth that has high values has not been widely utilized in the educational environment. The area around the Trenggalek area has not yet taken much advantage of the culture and values of local wisdom. The impact that occurs is the local knowledge of young people to culture is very low locality and often the character problems owned by the younger generation is not in accordance with the expectations of the surrounding community that has grown for many years. The development of technology and information (ICT) is not entirely positive for the development of society, but even the thinking of the younger generation is filled with the thought of postmodernism.

Much action needs to be done by the next generation to continue the development of the environment from various kinds of damage and pollution. Significant steps to solve environmental problems can be done through revitalizing the values of local wisdom to be transmitted in historical learning. Environmental problems occur due to the flow of globalization, natural exploitation, infrastructure development, the use of technology that is not environmentally friendly 
and the human mentality as a natural ruler. Children must be better stewards on the planet to get the most high-end solutions and solutions in natural maintenance efforts should be targeted based on cultural, national and economic diversity covering a wide range of environmental, (Ramanathan, Hahrie, \& Matlock, 2017) [7].

Environmental conditions in some schools Trenggalek there is still scattered rubbish. Water has not been used maximally, students' concern about the impact of using plastic, plastic bottles and the impact of the use of oil-fueled vehicles is not considered. Ability to preserve the environment in students in some schools Trenggalek still experience inequality in reaching clean Trenggalek. The main environments such as parks and streets around the city are clean, but the neighborhoods in the village and around the highway have not been so noticed. Cleanliness in urban areas is given to janitors while garbage and environment are managed by the community itself has not received maximum handling.

The values of local wisdom play a role in awaken the community in doing environmental maintenance. Based on the expression of A.Ag \& Febriansyah (2008, p 72) [8], local wisdom in the form of certain principles and ways adopted, understood, and applied by local communities in interacting and intertwining with their environment and transformed in the form of customary value systems and norms. Through the values of this local wisdom one can have a view of the outlook of civilization society in the form of local genius which became a reference behave and have attitude in accordance with the habits of society, community and individuals. The values of local wisdom of Turonggo Yakso art is the highest value owned by Trenggalek local people that can be transmitted in the form of learning materials. Cultural preservation of the existing regions in Indonesia reflects the spirit to encourage the progress of local wisdom in order to build a civilized nation that have a character.
The values of local wisdom formulated by character education based on education in Indonesia contained in the values of local wisdom of Turonggo Yakso art among others are the value of environmental care, cultural values, and the value of mutual cooperation. All of the three values are match the value of the character expected by Indonesian education in the young generation. In today's postmodern era, technological developments have made rapid progress and natural exploitation of industrialization progress will affect the decrease of natural resources or natural resources. The young generation as the successor agent of the nation's struggle can contribute in developing the potential of natural resources better if they have extensive knowledge and insight in order not easily lied to by the western people or someone who wants to master nature. Learning neighbor environment should start activated and carried out by all generations of the nation.

Learning should focus on trying to maximize the potential of nature, knowing what is being used and understanding sustainable development. Aspects of learning within the scope of school can not be separated from syllabus, curriculum, school environment culture, leadership and synergy relationship between community and school citizen. The result of the survey, interview and analysis show that many students from the school were not well aware of the environmental issues through their using of nylon, plastic bags, riding of hight pollutant emission vehicles.

Students' knowledge of local wisdom values of Turonggo Yakso art is also low, most students only know the Turonggo Yakso art movement without understanding the values contained therein. The values of local wisdom are appropriate values to be given to pupils because they seem not to indoctrinate students with various words in sentences and writing but tend to convey value in the form of visible movement, effort and the will of the ancestors to preserve the ecological wisdom that owned by the former community. 
The solution to facilitate the use of local wisdom values of Turonggo Yakso art in learning can be done by teachers through the use of local wisdom values of Turonggo Yakso art from research that has been done by existing research results. As for other solutions to more convincing the results of such research can be done through research assignments and simple interviews assigned to students. Needs analysis conducted in this study aims to assist teachers in implementing local wisdom values Turonggo Yakso art with direct research to local communities, artists Turonggo Yakso, and pioneer of art Turonggo Yakso.

2.2. Pattern of education through integration values of local wisdom Turonggo Yakso art in historical learning model

Through the analysis above, the problem of environmental awareness can be solve by implementing the local wisdom values Turonggo Yakso art that will be done in this learning aim to introduce local wisdom and local genius owned by the community in the immediate neighborhood of students in the Trenggalek district schools. Implementation of learning in schools is inseparable from the applicable curriculum then the values of local wisdom Turonggo Yakso art must be tailored to the values of characters teradapat in the curriculum. Teachers must understand how to integrate local wisdom well through the school curriculum, choosing the right subjects and selecting appropriate materials so that what they wish to convey is well accepted by the students through correct understanding.Schools should also provide support through cooperation in synergy with local communities.

Based on sociocultural theory Vygotsky argues that unlike animals that only react to the environment, humans have the capacity to change the environment according to their needs (Schunk, 2012, p.338) [9]. Introducing local knowledge into the classroom will be worthy of respect and well deserves as a way to solve the environmental awareness crisis for many general education schools, including those in other Sotheast Asia. The challenge is an issue that must be faced with preparation either through education or through community conditioning that synergizes with the government to keep its existing practices but still ignores the values of the good that already exists. The way a person interacts and communicates with their world to a particular institution, organization and or group of people can change one's mindset and perspective.

Starting with the exposure that has been described above, then the current generation environment in Trenggalek area needs to be done efforts to provide capacity ability to students in using the paradigm of thinking in accordance with the values prevailing in the environment. The environment is where students acquire knowledge for the first time, but if such knowledge is not understood wisely will be a blank message that has no meaning whatsoever.

\section{Conclusion}

Urgency implementation of local wisdom values of art Turonggo Yakso in the face of the current development of good times to do considering the younger generation easily influenced to the more logical western thought. The values of local wisdom can be integrated through historical learning and remain tailored to the values of characters formulated by the government so that the mission vision is expected to be achieved. Historical learning fits into a place to teach the values of the past that can be drawn as a basis for the emergence of life today. Historical learning model is used as a means to convey the values of local wisdom of Turonggo Yakso art in accordance with the syntax of learning for optimal and structured learning activities.

The values of local wisdom of Turonggo Yakso art is a value that has a high meaning to regulate one's behavior in running his life. The values contained there in are not myths but a values that society gains through interaction with the environment and society.Student character must be built through the process of 
enculturation in education both in school, family and society. Education becomes a place to integrate the values of local wisdom of Turonggo Yakso art as an effort to form the character of students in carrying out activities in the life of a cultured society. Trenggalek is a remote area that will experience cultural shock. In educational environment, the indigenous value should contribute to the solving of the problem of environment and sustainable development through the case study of the art of Turonggo Yakso.

\section{Reference}

[1] Geertz, C. (1973). The Interpretation of Cultures. USA: A Member of the Perseus Books Group.

[2] Muhaimin. (2015). Building Ecological Intelligence: Educational Models to Increase Ecological Competence. Bandung: Alfabeta.

[3] Kongprasertamorn, K. (2007). Local Wisdom, Environmental Protection and community development: the clam farmers in tabon
Bangkhsai, Phetchaburi Province, Thailand. Journal of Humanities.

[4] Bage, G. (2002). Narrative Matters: Teaching and Learning History through Story. New York: Falmer Press.

[5] Strauss, A. d. (1997). Basics of Qualitative Research, Technical Procedures, and Grounded Theory. Surabaya: Bina Ilmu.

[6] Sugiyono. (2012). Educational Research Methods. Bandung: Alfabeta.

[7] Ramanathan, V., Hahrie, H., \& Matlock, T. (2017). Educating Children to Bend the Curve: For a Stable Climate, Sustainable Nature and Sustainable Humanity. In AM Battro, P. Lena, MS Sorondo, \& J. v. Braun, Children and Sustainable Development: Eclogical Education in a Globalized World (page 5). Springer International Publishing AG.

[8] A.Ag, Z., \& Febriansyah, R. (2008). Local Wisdom and the Utilization and Conservation of Coastal Resources. Journal of Community Agribusiness, 1, 69-85, 72.

[9] Schunk, DH (2012). Learning Theories: An Educational Perspective Learning Theory of Educational Perspectives. (E. Hamidah, \& R. Fajar, Trans.) Yogyakarta: Student Literature. 